\title{
ISOLATION AND ANTIFUNGAL SUSCEPTIBILITY TESTING OF Trichosporon asahii IN CEARÁ, BRAZIL
}

Everardo Albuquerque MENEZES(1), José Arlécio de Sousa MARINHO(1), Maria Rozzelê F. ANGELO(2), Maria da Conceição dos Santos Oliveira CUNHA(1), Francisco Afrânio CUNHA(1) \& Antônio Alexandre de VASCONCELOS JÚNIOR(1)

\begin{abstract}
SUMMARY
Trichosporon spp. are yeasts capable of causing invasive disease, which mainly affect immunocompromised patients. A clinical strain of T. asahii was isolated from the blood cultures of patients admitted to the General Hospital of Fortaleza. Susceptibility tests were conducted by disk diffusion and broth microdilution. The isolated strain of T. asahii was resistant to fluconazole. The patient used amphotericin B and caspofungin in order to facilitate the microbiological cure. It was the first isolation and identification of $T$. asahii in blood culture in Ceará, Brazil.
\end{abstract}

KEYWORDS: T. asahii; Fluconazole; Amphotericin B; Caspofungin.

\section{INTRODUCTION}

Trichosporon are yeasts that belong to the basidiomycetes group, and may be found to be present in the external environment, primarily in the soil, but also in water, air, and organic substrates. The use of molecular biological techniques has led to the reorganization of the genus, with a proposed new classification that consists of 17 species and five varieties ${ }^{13}$. T. asahii and T. mucoides are associated with deep infections, while $T$. asteroides, $T$. ovoides and $T$. cutaneum are responsible for white piedra and other superficial infections. T. inkin is responsible for both superficial and deep infections, and cases of infection with $T$. pullulans have recently been reported ${ }^{1}$.

T. asahii is part of the cutaneous fungal microbiota present in humans. T. asahii of cutaneous origin may be one of the principal ways through which deep-seated trichosporonosis is acquired, whereas T. asahii taken from its natural environment is not associated with this infection ${ }^{15}$.

At present, there is little data on the susceptibility of T. asahii to antifungal agents. The fungus is known to exhibit variable susceptibility to amphotericin B (MIC 0.01 to $4 \mu \mathrm{g} / \mathrm{mL}$ ), and some studies revealed relative resistance to this agent ${ }^{4}$. The triazoles exhibit greater in-vitro activity when compared with amphotericin B, and some authors recommend combined treatment with the latter. Other in-vitro studies reported greater fungicidal action by triazoles such as voriconazole, posaconazole and ravuconazole ${ }^{11}$.

Reports of isolation of T. asahii from blood cultures are rare ${ }^{11}$, in
Ceará they are unknown. Very little is known about the susceptibility of these strains - mainly to fluconazole. The aim of this study was to isolate, identify and determine the susceptibility profile of one strain of Trichosporon spp isolated from a blood culture at the General Hospital of Fortaleza.

\section{MATERIALS AND METHODS}

The A.M.N. patient, male, 31 years old, underlying acute myeloid leukemia; had a fever and nosocomial infection, was a neutropenic, used chemotherapy drugs and antibiotics (rifampicin, imipenem and vancomycin), had a negative blood culture for bacteria and therefore used a prophylactic fluconazole. The patient underwent a chest drain, which was probably the source of the contamination. The blood sample was sent to the Laboratory, inoculated on potato dextrose agar and left to be incubated at $35{ }^{\circ} \mathrm{C}$ for 24 hours. T. asahii was isolated in three collections. The following indicators were used for identification: an API 20C AUX® kit for yeast identification (BioMérieux, Marcy-l'Étoile, France), fermentation and carbohydrate assimilation, susceptibility to cycloheximide, capacity for growth at different temperatures, growth in a chromogenic medium and micromorphology on a medium of rice agar Tween-80. The chromogenic medium was used for preliminary identification. Testing was carried out on a rice agar Tween-80, and we observed: the production of true hyphae with rectangular arthroconidia and the absence of appressoria that are characteristic of this species. This was additionally done with sugar assimilation tests.

The susceptibility of the T. asahii strain was evaluated by the disk

(1) Laboratory of Microbiology of Yeasts (LMY) Department of Clinical and Toxicological Analysis, College of Pharmacy, Federal University of Ceará. Tel. +55 8533668266.

(2) General Hospital of Fortaleza.

Correspondence to: Alexandre Vasconcelos, Rua Cap. Francisco Pedro 1210, 60430-370 Fortaleza, Ceará, Brasil. E-mail: alexandrevasconcelosjr@gmail.com 
MENEZES, E.A.; MARINHO, J.A.S.; ANGELO, M.R.F.; CUNHA, M.C.S.O.; CUNHA, F.A. \& VASCONCELOS JÚNIOR, A.A. - Isolation and antifungal susceptibility testing of Trichosporon asahii in Ceará, Brazil. Rev. Inst. Med. Trop. Sao Paulo, 54(1): 1-3, 2012.

diffusion method, in accordance with protocol M44-A of the Clinical and Laboratory Standards Institute (CLSI). Susceptibility to fluconazole and amphotericin B was also assessed through the broth microdilution method (protocol M27-A3) using RPMI, with the concentration of fluconazole ranging from 64 to $0.25 \mu \mathrm{g} / \mathrm{mL}$, and the concentration of amphotericin $\mathrm{B}$ ranging from 16 to $0.03 \mu \mathrm{g} / \mathrm{mL}^{2,3,9}$. The strain was classified according to the inhibition halos on the discs: halo $>19 \mathrm{~mm}$ (susceptible (S)); 14-19 $\mathrm{mm}$ (dose-dependent susceptible (DDS)); and < $14 \mathrm{~mm}(\operatorname{resistant}(\mathrm{R}))^{6,9,12}$. To test the microdilution for fluconazole, the breakpoints were: MIC susceptible $\leq 8 \mu \mathrm{g} / \mathrm{mL} ;$ DDS $=16-32 \mu \mathrm{g} / \mathrm{mL}$ and resistant $>64 \mu \mathrm{g} / \mathrm{mL}$; for amphotericin B: MIC susceptible $\leq 1 \mu \mathrm{g} / \mathrm{mL}$; MIC resistant $>1 \mu \mathrm{g}$ / $\mathrm{mL}$. The test for each sample was repeated twice. The strains Candida albicans ATCC 10231, C. albicans ATCC 14053 and C. parapsilosis ATCC 22019 were all used as controls.

\section{RESULTS AND DISCUSSION}

Disseminated trichosporonosis is a severe opportunistic mycosis and has a high mortality rate. However, the clinical features of the patients with Trichosporon and Candida could not be distinguished. The overall in-hospital mortality rate of trichosporonosis was $56.1 \%{ }^{8}$. In our study, the patient survived. The probable cause of infection was invasive medical procedures, however no epidemiological studies were undertaken to discover the origin from T. asahii.

The T. asahii strain was resistant to fluconazole by the disk diffusion and microdilution method with halo $=10 \mathrm{~mm}$ and $\mathrm{MIC}>64 \mu \mathrm{g} / \mathrm{mL}$ respectively, and exhibited susceptibility to amphotericin B with halo $=14 \mathrm{~mm}$ and MIC $=0.06 \mu \mathrm{g} / \mathrm{mL}$. When infected with T. asahii, immunocompromised patients can have a poor prognosis, and it is essential to identify and determine the susceptibility profile of the strain for the application of the appropriate therapy ${ }^{5}$.

The therapeutic response to new azoles such as voriconazole is quite promising. In a study of 101 strains of T. asahii isolated in Thailand, a low susceptibility to fluconazole and amphotericin B was observed, and voriconazole represented the best alternative ${ }^{8}$. In a study of 26 strains of T. asahii, high resistance to fluconazole was observed ${ }^{10}$. There is little data available regarding $T$. asahii's susceptibility to antifungal drugs in Brazil. The emergence of $T$. asahii with reduced susceptibility to common antifungal drugs is cause for concern ${ }^{14}$. In our study, resistance to fluconazole was detected, but the strain was susceptible to amphotericin B.

Recent studies demonstrate a synergy between caspofungin and amphotericin B. However, it is difficult to explain how the echinocandin MICs are lowered when the drug is together with amphotericin $\mathrm{B}^{7}$. In our study, the patient used amphotericin B together with caspofungin and was cured of the fungal infection. Caspofungin was used for 12 days and amphotericin was used for nine days and the T. asahii culture turned negative.

The most common underlying conditions related to trichosporonosis were hematological diseases, peritoneal dialysis and solid tumor. Trichosporonemia occurred in 115 out of the 154 (74.7\%) patients and disseminated infection occurred in 78 out of the 154 (50.6\%) cases. The majority of cases of trichosporonosis were reported in North American medical centers (33.9\%), followed by Europe (27.6\%) and Asia (23.3\%).
Only six cases were reported in South American institutions, including five cases in Brazil and one case in Argentina ${ }^{1}$. There are no studies on the cases and identification of T. asahii in blood cultures in Ceará, Brazil. Further studies with a higher number of strains may assist in understanding the mechanisms of resistance of this yeast.

\section{RESUMO}

\section{Isolamento e teste de susceptibilidade aos antifúngicos de Trichosporon asahii no Ceará, Brasil}

Trichosporon spp. são leveduras capazes de causar doença invasiva, que afetam principalmente pacientes imunocomprometidos. Uma cepa clínica de T. asahii foi isolada em hemocultura de paciente internado no Hospital Geral de Fortaleza. Os testes de suscetibilidade foram realizados por difusão em disco e microdiluição em caldo. A cepa isolada do $T$. asahii foi resistente ao fluconazol, o paciente fez uso de anfotericina B e caspofungina então a cura microbiológica ocorreu. Foi o primeiro isolamento e identificação de T. asahii em hemocultura no Ceará,Brasil.

\section{REFERENCES}

1. Chagas-Neto TC, Chaves GM, Colombo AL. Update on the genus Trichosporon. Mycopathologia. 2008;166:121-32.

2. Clinical and Laboratory Standards Institute (CLSI). Method for antifungal disk diffusion susceptibility testing of yeasts. Approved standard M44-A. Wayne, PA: National Committee for Clinical Laboratory Standards; 2004.

3. Espinel-Ingroff A. Standardized disk diffusion method yeast. Clin Microbiol Newsl. 2007;29(13):97-100

4. Fagundes Júnior AAP, Carvalho RT, Focaccia R, Fernandez JG, Araújo HBN, Strabelli TMV, et al. Emergência de infecção por Trichosporon asahii em pacientes portadores de insuficiência cardíaca em unidade de terapia intensiva cardiológica: relato de caso e revisão da literatura. Rev Bras Ter Inten. 2008;20:106-9.

5. Falk R, Wolf DG, Shapiro M, Polacheck I. Multidrug-resistant Trichosporon asahii isolates are susceptible to voriconazole. J Clin Microbiol. 2003;41:911.

6. Fothergill AW, Rinaldi MG, Sutton DA. Antifungal susceptibility testing. Infect Dis Clin N Am. 2006;20:699-709.

7. Li H, Lub Q, Wanb Z, Zhang J. In vitro combined activity of amphotericin B, caspofungin and voriconazole against clinical isolates of Trichosporon asahii. Int J Antimicrob Agents. 2010;35:550-2.

8. Mekha N, Sugita T, Ikeda R, Nishikawa A, Autthateinchai R, Poonwan N, et al. Genotyping and antifungal drug susceptibility of the pathogenic yeast Trichosporon asahii isolated from Thai patients. Mycopathologia. 2010;169:67-70.

9. Menezes EA, Mendes LG, Cunha FA. Resistência a antifúngicos de cepas de Candida tropicalis isoladas no Ceará. Rev Soc Bras Med Trop. 2009;42:354-5.

10. Netsvyetayeva I, Swoboda-Kopec E, Paczek L, Fiedor P, Sikora M, Jaworska-Zaremba $\mathrm{M}$, et al. Trichosporon asahii as a prospective pathogen in solid organ transplant recipients. Mycoses. 2009;52:263-5.

11. Paphitou NI, Ostrosky-Zeichner L, Paetznick VL, Rodriguez JR, Chen E, Rex JH. In vitro antifungal susceptibilities of Trichosporon species. Antimicrob Agents Chemother. 2002;46:1144-6

12. Pfaller MA, Diekema DJ, Gibbs DL, Newell VA, Bijie H, Dzierzanowska D, et al Results from the ARTEMIS DISK Global Antifungal Surveillance Study, 1997-2007: 10.5-year analysis of susceptibilities of non-Candida yeast species to fluconazole 
MENEZES, E.A.; MARINHO, J.A.S.; ANGELO, M.R.F.; CUNHA, M.C.S.O.; CUNHA, F.A. \& VASCONCELOS JÚNIOR, A.A. - Isolation and antifungal susceptibility testing of Trichosporon asahii in Ceará, Brazil. Rev. Inst. Med. Trop. Sao Paulo, 54(1): 1-3, 2012.

and voriconazole determined by CLSI standardized disk diffusion testing. J Clin Microbiol. 2009;47:117-23.

13. Pini G, Faggi E, Donato R, Fanci R. Isolation of Trichosporon in a hematology ward Mycoses. 2005;48:45-9.

14. Silva RBO, Fusco-Almeida AM, Matsumoto MT, Baeza LC, Benaducci T, MendesGiannini MJS. Genetic diversity and antifungal susceptibility testing of Trichosporon asahii isolated of intensive care units patients. Braz J Microbiol. 2008;39:585-92.
15. Zhang E, Sugita T, Tsuboi R, Yamazaki T, Makimura K. The opportunistic yeast pathogen Trichosporon asahii colonizes the skin of healthy individuals: analysis of 380 healthy individuals by age and gender using a nested polymerase chain reaction assay. Microbiol Immunol. 2011;55:483-8.

Received: 01 June 2011

Accepted: 07 November 2011 